Original Research Paper

\title{
Mengenal Fitoplankton untuk Penguatan Materi Kompetensi Dasar Protista Pada Siswa Jurusan IPA (Biologi) MA Hidayatul Muhsinin Desa Labulia Lombok Tengah
}

\author{
Lalu Japa ${ }^{1 *}$, Syamsul Bahri ${ }^{1}$, Prapti Sedijani ${ }^{1}$ \\ ${ }^{1}$ Program Studi Pendidikan Biologi, Fakultas Keguruan dan Ilmu Pendidikan Universitas Mataram, Indonesia
}

\author{
*Corresponding Author: \\ Lalu Japa, Program Studi \\ Pendidikan Biologi, \\ Fakultas Keguruan dan \\ Ilmu Pendidikan \\ Universitas Mataram, \\ Indonesia; \\ Email:1japa@unram.ac.id
}

\begin{abstract}
Abstrak: Berdasarkan kajian nilai ujian nasional Sekolah Mengengah Atas (SMA) dan Madrasah Aliyah (MA) tiga tahun berturut-turut (2008-2010) untuk kompetensi dasar (KD) yang nilainya selalu rendah adalah KD Protista. Dari hasil penelitian tahun 2010, terungkap bahwa kegiatan parktikum (termasuk pengamatan Protista) tidak bisa dlaksanakan secara maksimal karena berbagai kendala seperti mulai dari tidak cukup tersedia sarana pendukung, tidak cukup waktu, dan tidak tahu bagaimana melakukan kegiatan tersebut. Karena itu diperlukan kegiatan khusus pengenalan fitoplankton sebagai salah satu upaya penguatan materi Protista yang menyangkut: pengenalan spesies yang umum dijumpai, sumber sampel, dan teknik pengamatan dengan mikroskop. Kegiatan pengabdian ini ditujukan untuk penguatan atau pengayaan pengetahuan dan keterampilan siswa MA Hidayatul Muhsinin Desa Labulia Lombok Tengah tentang fitoplankton sebagai komponen utama materi KD Protista. Kegiatan pengabdian ini akan dilakukan dalam bentuk penyampaian teori dan praktek pengamatan secara langsung menggunakan mikroskop. Siswa kelas III jurusan IPA (Biologi) MA Hidayatul Muhsinin, peserta kegiatan ini sangat bersemangat melakukan pengamatan di bawah mikroskop yang sebelumnya belum pernah mereka lakukan. Mereka baru sadar bahwa dalam satu tetes air terdapat banyak sekali individu sel berbagai spesies fitoplankton yang bisa disaksikan. Pembelajaran teoritis di kelas diperkuat dengan fakta yang diamati dengan mikroskop.
\end{abstract}

Kata kunci: IPA(Biologi), Fitoplankton, Madrasah Aliyah, Penguatan, Protista, Siswa

\section{Pendahuluan}

Dalam dunia taksonomi organisme dikenal Protista sebagai salah satu kingdom (kingdom Protista). Organisme dalam Kingdom Protista dikelompokkan menjadi protista mirip hewan dan protista mirip tumbuhan. Protista mirip tumbuhan biasa disebut sebagai alga atau ganggang. Alga itu sendiri dikelompokkan menjadi makroalga dan mikroalga. Kelompok protista mirip tumbuhan sebagai mikroalga kemudian lebih umum dikenal dengan istilah fitoplankton. Materi pembelajaran biologi SMA/MA tentang mikroalga (fitoplankton) tertuang dalam kurikulum sebagai pokok bahasan tersendiri yaitu kompetensi dasar (KD): 3.6 Menyajikan data hasil identifikasi Kingdom Protista berdasarkan ciri-ciri yang dapat diamati (Depdiknas, 2003).

Fitoplankton sebagai kelompok organisme berukuran mikroskopis tidak bisa dilihat atau diamati dengan mata telanjang, melainkan dengan alat bantu khusus yaitu mikroskop, mulai dari mikroskop cahaya biasa sampai mikroskop elektron. Secara kasap mata, keberadaan fitoplankton dalam kolom air dapat disaksikan sebagai warna hijau. Namun untuk dapat melihat morfologi individual selnya harus dengan mikroskop.

Kondisi sebagaimana dijabarkan di atas menjadi sebab utama pembelajaran KD Protista itu 
tidak bisa maksimal. Kegiatan penelitian dan pengabdian masyarakat yang dilakukan secara berturut-turut pada tahun 2010 (Sridana et al., 2010) dan 2011 (Sridana et al., 2011) ditemukan beberapa permasalahan dalam pembelajaran IPA(Biologi) khususnya pada KD Protista. Salah satu permasalahan tersebut adalah kegiatan praktikum tidak dilaksanakan karena berbagai alasan mulai dari sarana tidak mendukung, tidak cukup waktu, dan tidak tahu bagaimana melakukan praktikum terutama yang terkait dengan pengamatan Protista. Bahkan masih ada guru melaksanakan kegiatan praktikum cukup dengan menayangkan gambar melalui poster atau slide LCD.

Tujuan dilakukan kegiatan pengabdian masyarakat ini ialah memberikan pengayaan dan penguatan materi pembelajaran KD Protista melalui kombinasi pembelajaran klasial dan pengamatan langsung menggunakan mikroskop. Manfaat yang diharapkan dengan adanya kegiatan pengabdian ini diantaranya ialah dapat memberikan tambahan pengetahuan dan pengalaman langsung kepada siswa jurusan IPA (Biologi) MA Hidayatul Muhsinin Desa Labulia Lombok Tengah. Kegiatan pengabdian ini diharapkan dapat bermanfaat untuk komptensi akademik mereka dalam mempelajari KD Protista tidak saja secara teoritis tetapi juga pengamatan langsung melalui kegiatan praktikum. Dengan demikian diharapkan dapat berimbas pada peningkatan prestasi siswa yang diwujudkan dengan peningkatan nilai ujian nasional pada KD Protista tersebut secara khusus.

Luaran yang diharapkan dari kegiatan pengabdian masyarakat ini ialah meningkatnya pengetahuan siswa jurusan IPA-Biologi MA Hidayatul Muhsinin Desa Labulia Lombok Tengah, pada KD Protista, termasuk mulai dari pengenalan spesies Protista yang mumum dan mudah dijumpai (diamati), sumber sampel, dan teknik pengamatan di bawah mikroskop. Dengan demikian diharapkan terjadinya peningkatan kegiatan pembelajaran terutama kegiatan praktikum yang pada akhirnya peningkatan nilai siswa.

\section{Metode Pelaksanaan}

Bahan dan perlalatan yang digunakan dalam kegiatan pengabdian ini meliputi bahan dan alat untuk pembelajaran teori di kelas dan bahan dan alat untuk pengamatan langsung. Perlengkapan pembelajaran (LCD, Power Point, dan alat tulis lainnya) digunakan dalam pembelajaran teori di dalam kelas. Sedangkan bahan dan peralatan untuk pengamatan langsung meliputi: sampel air (sampel plankton) yang sudah diawet dengan pengawet formalin $40 \%$, mikroskop, pipet tetes, gelas benda dan gelas penutup. Sampel air (sampel plankton) dalam pengawetan $4 \%$.

Pelaksanaan kegiatan dilakukan dalam bentuk penyampaian materi (teori) di kelas dan praktek pengamatan secara langsung menggunakan mikroskop. Sasaran kegiatan ini adalah siswa kelas III jurusan IPA-Biologi MA Hidayatul Muhsinin Desa Labulia Lombok Tengah. Pada kegiatan praktik pengamatan Protista juga dijelaskan beberapa hal seperti: (1) sumber sampel, (2) teknik sampling (pengambilan sampel), (3) pengawetan sampel, dan (4) teknik identifikasi, termasuk teknik koleksi gambarnya. Kegiatan pembelajaran klasikal menggunakan kombinasi metode ceramah, diskusi, dan tanya jawab, dengan topik materi "Fitoplankton sebagai anggota Divisi Protista". Selama kegiatan pengamatan Protista menggunakan mikroskop, siswa secara bergantian membedik dan mengamati individual sel beberapa spesies Protista (fitoplankton) yang dapat diamati.

\section{Hasil dan Pembahasan}

Pada dokumen kurikulum disebutkan, bahwa kompetensi siswa adalah kemampuan dasar siswa yang diartikan sebagai uraian kemampuannya dalam menguasai bahan dan lingkup ajar secara maju dan berkelanjutan. Selanjutnya, dalam dokumen Kurikulum Berbasis Kompetensi yang diterbitkan bulan Agustus 2001, Balitbang (2001), mengganti istilah kemampuan dasar dengan kompetensi. Lebih lanjut dijabarkan, kompetensi dalam dokumen terakhir ini, dirumuskan sebagai uraian kemampuan yang memadai atas pengetahuan, keterampilan, dan sikap mengenai materi pokok (Balitbang, 2001). Kemampuan itu harus dikembangkan secara maju dan berkelanjutan seiring dengan perkembangan siswa. Berdasarkan pengertian tersebut, kompetensi diartikan sebagai kemampuan yang harus dikuasai seorang peserta didik. Depdiknas (2005) mendefinisikan kompetensi sebagai pengetahuan, keterampilan, dan nilai-nilai dasar yang direfleksikan dalam kebiasaan berfikir dan bertindak. Syah (2000) menyatakan, "kompetensi" 
adalah kemampuan, kecakapan, keadaan berwenang, atau memenuhi syarat menurut ketentuan hukum. Pengertian tersebut dapat dikatakan sejalan dengan apa yang dikemukakan oleh Wolf (1995), Debling (1995), Kupper dan Palthe. Wolf (1995:40) dalam Ansyar (2001) mengatakan "competence pertains to the ability to perform the activities within a function or an occupational area to the level of performance expected in employment". Sedangkan Kupper dan Palthe mengatakan "competencies as the ability of a student/worker enabling him to accomplish tasks adequaletym to find solutions and to realize them in work situations" (Ansyar, 2001).

Pada sistem pembelajaran saat ini, pengembangan kompetensi tidak dapat dipisahkan dari standar mutu pendidikan. Jika pada masa awal, pendekatan kompetensi dikembangkan secara lokal berdasarkan tuntutan yang teridentifikasi dari apa yang berkembang dalam masyarakat dan kompetensi tidak dikaitkan dengan standar. Tucker dan Coding (1998) dalam Ansyar (2001) menyatakan, standar dirumuskan sebagai pernyataan menegnai kualitas yang harus dikuasai dan dapat dilakukan siswa dalam suatu pelajaran, yang ditentukan sejak awal, disetujui oleh para ahli pendidikan dan masysrakat, terukur, dan digunakan untuk mengembangkan materi, proses belajar serta evaluasi hasil belajar.

Rendahnya perolehan nilai ujian nasional pada Kompetensi Dasar Protista tersebut disebabkan oleh bukan saja terbatasnya sarana dan prasarana pendukung tetapi juga oleh ketidaktahuan sebagian besar siswa termasuk guru mengenai sumber, cara dan teknik pengamatan langsung terhadap Protista. Karena itu, melalui kegiatan pengenalan fitoplankton dengan pengamatan langsung terhadap sampel Protista bagi siswa jurusan IPA-Biologi MA Hidayatul Muhsinin Desa Labulia Lombok Tengah diharapkan dapat memberikan penguatan atau pengayaan pengetahuan dan pengalaman langsung dan aktual bagi siswa dalam mengenal Protista.

Penguatan materi KD Protista dilakukan pembelajaran klasikal disertai pengamatan langsung menggunakan mikroskop terhadap sampel plankton. Dalam pembelajaran klasikal disampaikan materi dengan topik khusus "fitoplankton Protista". Fitoplankton sebagai komponen Protista dijabarkan lebih luas dalam pembahasan di bawah ini.

Secara umum, Protista tumbuhan adalah plankton alga mikroskopis (microscopic planktonic algae) atau populer dengan sebutan mikroflora atau fitoplankton. Mereka dibedakan atas dua kelompok besar yaitu, dinoflagellata (Divisi Dinophyta) dan diatom (Divisi Bacillariophyta). Namun anggota dari Divisi Cyanophyta dan Chlorophyta juga sering banyak ditemukan dalam satu sumber sampel yang sama.

Divisi Dinophyta dikenal dengan Pyrrophyta. Sebagian anggota divisi ini memiliki fisiologi seperti hewan, maka lebih dikenal dengan Dinoflagellata. Anggota kelompok Dinophyta telah dikenal dengan baik sekali sebagai kontributor terhadap fenomena "red tide" (pasang berwarna) yang mungkin mengandung jenis yang sangat beracun bagi kehidupan organisme air lainnya dan juga manusia. Samudra et al. (2013) menyatakan, bahwa Dinoflagellata air tawar umumnya tidak beracun dan tidak berbahaya seperti Dinoflagellata air laut yang bersifat toksik. Beberapa anggota Dinophyta yang paling umum dijumpai dimana saja (terutama air laut) adalah Ceratium spp., Dinophysis spp., Protoperidinium spp., Prorocentrum spp., Gymnodinium spp., dan Piridinium spp. Anggota devis Bacillariophyta air tawar yang mudah dijumpai antara lain: Navicula, Fragilaria, Pinularia, dan Suriella.

Kelompok diatom (Bacillariophyta) terdiri dari 2 ordo, 5 sub-ordo, 21 famili dan sekitar 550010.000 species. Bacillariophyta termasuk divisi alga yang terkaya dengan jumlah species, dan pemanfaatannya terus meningkat untuk memonitor kondisi ekologi perairan. Berdasarkan simetri morphologi tubuhnya, spesies-spesies diatom dibedakan atas dua group besar, yaitu diatom batangan (pennate) masuk dalam ordo Pennales dan diatom lingkaran (centric) yang merupakan anggota dari ordo Centrales. Contoh group diatom batangan yang paling umum dijumpai hampir diseluruh perairan laut antara lain: Nitzschia spp., Navicula spp., Asterionelopsis spp., Pseudo-nitzschia spp., Cocconeis spp., Bacillaria spp., Epithemia spp., Amphora spp., dan Pleurosigma spp.. Sedangkan contoh diatom yang berbentuk lingkaran yang umum dijumpai adalah Coscinodiscus spp., Rhiszosolenia spp., Thalassiosira spp., Skeletonema spp., Melosira spp., Bacteriastrum spp., Cyclotella spp., dan Chaetoceros spp.

Mikro Chlorophyta bersifat uniselluler soliter atau koloni. Mereka memiliki klorofil a dan b dan bermacam variasi karotenoid. Cadangan makannya berupa zat tepung (amilum) yang tersimpan di dalam plastida. Dinding selnya terbentuk dari polysakarida, 
kadang-kadang sellulosa. Ada sekitar 7000 spesies yang telah diketahui: Klas Charophyceae, uniselluler, berkoloni dalam jumlah sel terbatas, dan berupa filamen (alga benang). Sel-sel bergerak memiliki dua flagella. Dominan hidup di air tawar. Klas Chlorophyceae, sel-sel beregeraknya berflagella dua, empat atau banyak. Dominan terjadi pada air tawar (Raven et al., 1992). Contoh genus Divisi Chlorophyta yang umum ditemukan pada sampel air tawar, termasuk pada sampel air kolam budidaya ikan air tawar di Lingsar Lombok Barat meliputi: Actinastrum, Pediastrum, Phacus, dan Scenedesmus. Actinastrum, Pediastrum, dan Scenedesmus juga teridentifikasi di Sungai Kelingi Kota Lubuklinggau Sumatera Selatan (Harmoko dan Sepriyaningsih, 2018). Chlorella sp., salah satu anggota dari divisi Chlorophyta bahkan sudah dikembangkan menjadi bahan makanan (Rasyid, 2009).

Pada tulisan ini juga ditampilkan gambaran singkat profil komunitas mikro-flora yang berhasil diidentifikasi di perairan Lembar Lombok. Profil terbatas ini diharapkan dapat memberikan gambaran obyektif, bahwa beberapa kelompok mikro-flora berbahaya ternyata secara menyakinkan keberadaannya di perairan pulau Lombok.

Japa (2000) melaporkan, dari total 178 spesies mikro-flora yang berhasil diidentifikasi, kelompok yang potensial penghasil racun meliputi genus Amphora (2 spesies), Bactriastrum (4 spesies), Chaetoceros (23 spesies), Nitzschia (12 spesies), Pseudo-nitzschia (6 spesies), Thalassiosira (10 spesies), Dinophysis (5 spesies), Gonyaulax (2 spesies), Peridinium (2 spesies), dan Prorocentrum (2 spesies) secara menyakinkan keberadaannya di perairan pelabuhan Lembar Lombok. Kehadiran mikroflora ini di perairan pulau Lombok perlu diwaspadai kemungkinan efek negatifnya. Terlebihlebih dengan kehadiran genus Pseudo-nitzschia, group alga yang paling berbahaya (ditakuti) di pantai barat Amerika Serikat (Horner et al., 1997). Lima spesies (Pseudo-nitzschia fraudulenta, P. granii, $P$. pungens, $P$. pseudodelicatissima, dan $P$. turgidula) secara menyakinkan teridentifikasi di perairan pelabuhan Lembar, Lombok Barat, Nusa Tenggara Barat (Japa, 2000). Bates et al., (1989) melaporkan, bahwa $P$. pungens, dan $P$. pseudodelicatissima disamping $P$. multiseries, $P$. asutralis, $P$. delicatissima, dan $P$. seriata adalah spesies-spesies penghasil asam domoic (domoic acid).
Keberadaan Chaetoceros dengan 23 spesies juga patut diperhitungkan, mengingat kelompok mikro-flora ini terlah banyak dilaporkan sebagai penyebab mati masalnya ikan karena pendarahan organ insang. Jumlah spesies dari genus Chaetoceros dilaporkan mendominasi spesies yang lain di perairan pantai kawasan Pulau Lombok (Japa, 2000, Japa dan Suripto, 2003, Japa dan Karnan, 2007, Japa et al. 2013, Japa \& Khairuddin, 2014. Diatom genus Chaetoceros juga dilaporkan sebagai komponen fitoplankton laut yang melimpah, dengan jumlah jenis sangat banyak (Hernandez-Becerril, 1996).

Profil terbatas mengenai komunitas mikroflora perairan Lembar Lombok ini, selanjutnya diharapkan dapat meningkatkan kewaspadaan terutama pada musim-musim tertentu yang dapat menjadi pemicu kedaan blooming. Keadaan blooming mikro-flora di daerah tropika belum dilaporkan, namun karena perubahan iklim secara menyeluruh akibat panas global, mungkin saja menjadi pemicu terjadinya blooming. Kedaan ini akan lebih dipacu lagi dengan banyaknya bentuk aktivitas masyarakat didaratan maupun dilautan potensial menjadi penyebabkan melimpahnya zatzat nutrisi yang dialirkan dari areal pertanian, selokan, kali ke badan air (laut, dam, dan danau) yang dikenal dengan istilah eutropikasi. Eutropikasi selanjutnya sangat diyakini sebagai salah satu faktor yang berpotensi menyebabkan bloomingnya kelompok tertentu mikro-flora sebagaimana yang banyak dilaporkan terjadi di negara-negara lainnya. Pola aktivitas dibidang pertanian dengan sistem intensifikasi sangat besar peluangnya menyumbangkan tambahan nutrisi yang lebih dari cukup ke badan perairan. Tingginya kadar nutrisi lingkungan dipengaruhi oleh limah domestik dan industri (Meksumpun et al., 1995) dan aliran dari daratan (Horner et al., 1997).

\section{Kesimpulan}

Madrasah Aliyah Hidayatul Muhsinin belum memiliki fasilitas laboratorium untuk kegiatan praktikum. Pembelajaran materi kompetensi dasar Protista belum bisa dilaksanakan secara maksimal di MA Darul Muhsinin karena keterbatasan sarana dan prasarana pendukungya, terutama perangkat laboratoriumnya. 


\section{Ucapan Terimakasih}

Terima kasih disampaikan kepada Rektor Universitas Mataram dan Ketua LPPM Universitas Mataram atas dukungan dana untuk terlaksananya kegiatan pengabdian kepada masyarakat ini. Terima kasih juga kepada Tim Reviuwer LPPM Universitas Mataram yang telah meloloskan usulan kegiatan pengabdian kepada masyarakat ini. Penerimaan dan dukungan Kepala Sekolah, Guru Biologi, dan siswa kelas III Jurusan IPA (Biologi) MA Hidayatul Muhsinin, Labulia Lombok Tengah juga disampaikan terima kasih.

\section{Daftar Pustaka}

Ansyar, M. 2001. Kurikulum Menyonsong Otonomi Pendidikan di Era Globalisasi : Peluang, tantangan, dan Arah". Forum Pendidikan, 2 (26) : 103-112.

Balitbang. 2001. Kurikulum Berbasis Kompetensi. Diknas. Jakarta.

Bates, S.S., C.J. Bird, A.S.W. de Freitas, R.A. Foxall, M.W. Gilgan, L.A. Hanic, G.E. Johnson, A.W. McCulloch, P. Odense, R. Pocklington, M.A. Quilliam, P.G. Sim, J.C. Smith, D.V. Subba Rao, E.C.D. Todd, J.A. Walter, and J.L.C. Wright. 1989. Pennate Diatom Nitzschia pungens as the Primary Source of Domoic Acid, a Toxin in Shellfish from Eastern Prince Edward Island, Canada. Canadian Journal of Fisheries and Aquatic Sciences, 46: 1203-1215.

Depdiknas. 2003. Standar Kompetensi Mata Pelajaran Biologi Sekolah Menengah Atas dan Madrasah Aliyah. Jakarta. Pusat Kurikulum, Balitbang, Departemen Pendidikan Nasional.

Depdiknas. 2005. PP No. 19 Tahun 2005. tentang Standar Nasional Pendidikan. Diknas. Jakarta.

Harmoko dan Sepriyaningsih. 2018. Keanekaragaman Mikroalga Chlorophyta Di Sungai Kelingi Kota Lubuklinggau Sumatera Selatan. Jurnal Pro-Life, 5(3):666-676.

Hernandez-Becerril, D.U. 1996. A Morphological Study of Chaetoceros Species (Bacillariophyta) from the Plankton of the Pacific Ocean of Mexico. Bull, Nat, Hist, Mus, Lond, (Bot.), 26(1): 1-73.
Horner, R.A., D.L. Garrison, and F.G. Plumley. 1997. Harmful Algal Blooms and Red Tide Problems on the U.S. West Coast. Limnology and Oceanography, 42(5, part 2): 1076-1088.

Japa, L. 2000. Seasonal Succession of Phytoplankton Communities in Lombok Indonesian Coastal Waters, with Emphasis on Species of the Diatom Genera Pseudo-nitzshia and Thalassiosira. Thesis Program Master. Universitas Tasmania.

Japa, L. dan Suripto. 2003. Inventarisasi Spesies Fitoplankton Di Kawasan Perairan Budidaya Kerang Mutiara Dadap Sambelia Lombok Timur. Laporan Penelitian. Lembaga Penelitian Universitas Mataram.

Japa, L. dan Karnan. 2007. Studi Komunitas Fitoplankton Di Perairan Pantai Kota Mataram. Jurnal Biologi Tropis, Vol. 8 (1): 7-12.

Japa, L., Suripto, dan I.G. Mertha. 2013. Hubungan Kuantitatif Fitoplankton Dan Zooplankton Perairan Suaka Perikanan Gili Ranggo Teluk Serewe Lombok Timur. Jurnal Biologi Tropis, 13(1): $45-54$

Japa, L. dan Khairuddin. 2014. Komunitas Fitoplankton Perairan Pantai Utara, Timur, Dan SelatanPulau Lombok. Jurnal Biologi Tropis. 14(2):100-107.

Meksumpun, S., S. Montani, K. Ichimi, K. Tada, S. Yoshimatsu, and T. Okaichi. 1995. Relationships between the Biochemical Composition and the Environmental Conditions of Gymnodinium sp. Red Tide in the Seto Inland Sea, In: Harmful Marine Algal Blooms: Proceedings of the Sixth International Conference on Toxic Marine Phytoplankton, October 1993, Nantes, France, P. Lassus, G. Arzul, E. Erard, P. Gentien, and C. Marcaillou (Editors), Technique \& DocumentationLavoisier. Intercept Ltd. New York.

Rasyid, A. 2009. Berbagai manfaat algae. Oseana, 29(3): 9-15.

Raven, P.H., R.F. Evert dan S.E. Eichhorn. 1992. Biology of Plants. $5^{\text {th }}$ eddition. Worth Publishers Inc. USA.

Samudra, S.R., T.R. Soeprobowati, dan M. Izzati. 2013. Komposisi, Kemelimpahan dan Keanekaragaman Fitoplankton Danau Rawa Pening Kabupaten Semarang. Bioma, 15(1): 613.

Sridana, I.N., M. Sulaimi, M., L. Japa, Hariyanto, S. Willian, dan Kaharuddin. 2010. Pemetaan 
Kompetensi Peserta Didik dan Pengembangan Mutu Pendidikan Sekolah Menengah Atas Di Kabupaten Lombok Tengah Provinsi Nusa Tenggara Barat. Laporan Penelitian. Puslit, Universitas Mataram

Sridana, I.N., M. Sulaimi, M., L. Japa, Hariyanto, S. Willian, dan Kaharuddin. 2011. Sosialisasi dan Workshop Model Pengembangan Mutu Pendidikan pada Guru Sekolah Menengah Atas Di Kabupaten Lombok Tengah Provinsi Nusa Tenggara Barat. Laporan Pengabdian Kepada Masyarakat. LPM, Universitas Mataram

Syah, M. 2000. Psikologi Pendidikan dengan Pendekatan Baru. Bandung: PT Remaja Rosdakarya.Taylor, F.J.R. (Editor). 1987. The Biology of Dinoflagellates. Botanical Monographs. Blackwell Scientific Publications. 